\section{THE EFFECT OF SEA WATER IMMERSION ON BUTON ASPHALT (AS-BUTON) MIXTURE}

\author{
Gito Sugiyanto*, Wahyu Widarini, Eva Wahyu Indriyati
}

Civil Engineering Department, Faculty of Engineering, Jenderal Soedirman University. Mayjend. Sungkono Street, Km. 5, Blater, Kalimanah, Purbalingga, Central Java, Indonesia Postcode 53371
Article history

Received

31 March 2021

Received in revised form

30 September 2021

Accepted

7 October 2021

Published Online

20 December 2021

*Corresponding author gito.sugiyanto@unsoed.ac.id

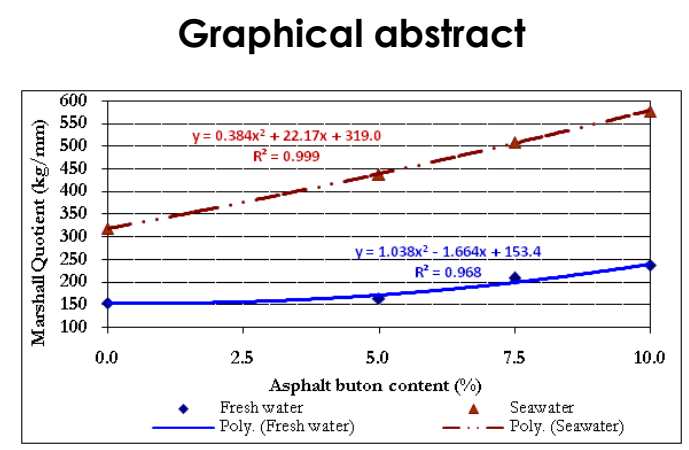

\begin{abstract}
One of the causes of flexible pavement damage is being submerged in water with a high acidity, such as seawater. To overcome this condition, a study on the use of buton asphalt (as-buton) was conducted. The advantages of as-buton are that it has higher adhesion and is more resistant to temperature changes. As-buton modification by mixing Lawele as-buton Southeast Sulawesi with oil asphalt pen 60/70. This study focuses on determining the effect of the addition of as-buton to the modified asphalt mixture and the effect of seawater immersion on as-buton mixture based on the Marshall characteristic test. The percentage by weight of as-buton used is $5 \%, 7.5 \%$, and $10 \%$. The immersion was carried out in freshwater and seawater immersion for up to 24 hours at a temperature of $30^{\circ} \mathrm{C}$. The result of this study show that the addition of as-buton increase the value of stability, void in mixture, Marshall quotient (MQ), and void in mineral aggregate, but reduce the flow, void filled with asphalt, and density. The increase of stability and $M Q$ value in seawater-immersion due to the addition of as-buton was higher than that in freshwater. The stability value of the $10 \%$ modified asbuton mixture in freshwater-immersion increased by $169.338 \mathrm{~kg}(14.61 \%)$ and in seawater-immersion increased by $1261.669 \mathrm{~kg}(55.65 \%)$. The flow value in freshwater-immersion decreased by $1.9 \mathrm{~mm}(25.33 \%)$ while in seawaterimmersion decreased by $1 \mathrm{~mm}(14.08 \%)$. For further research, variations in the addition of as-buton will be carried out to produces a modified asphalt mixture with the best performance.
\end{abstract}

Keywords: Marshall characteristics, as-buton, asphalt concrete wearing course, sea water immersion, asphalt mixture

(C) 2022 Penerbit UTM Press. All rights reserved

\subsection{INTRODUCTION}

One type of road pavement construction is flexible pavement, namely pavement using asphalt as a binding material. Flexible pavement consists of pavement layers that carry and spread traffic loads to the subgrade. Flexible pavement is a composite material consisting of aggregate, asphalt mastic, air void, and filler. It is considered the primary paving type of road, taxiway, and runway, due to their good riding quality, fast construction speed, low noise, excellent durability, and stability [1], recyclability, and easy maintenance [2], [3]. In last decades, Indonesia intended to improve infrastructure by 
increasing highway network and building the asphalt pavement almost 329,926 km [4]. In China more than $90 \%$ is flexible pavement [5] and in the United State of America, flexible pavements represent $95 \%$ of total pavement [6].

Asphalt surface layer plays a fundamental role in flexible pavement structure, withstanding varying traffic loads and constantly changing environmental conditions. However, under the effects of repeated vehicle loading flexible pavements are susceptible to thermal cracking, low temperatures, and freeze-thaw cycles [7]. Many factors cause damage to flexible pavements. Asphalt pavement degradation is an inevitable phenomenon due to combined effects of high traffic loads or overloading, low speed vehicles [8] [9] and harsh environmental conditions. Environmental conditions include unstable subgrade conditions, temperature, weather, and water. Water is the main destroyer of road pavement. Especially water that has a high level of acidity such as sea water can affect the bond between asphalt and aggregate which accelerates oxidation, causing premature damage to the road surface layer. The influence of climate change causes natural phenomena such as tides, winds, waves, and ocean currents, which have a significant effect in parts of Indonesia, in coastal areas. The phenomenon of rising sea water causes tidal flooding so that roads near coastal areas are prone to experiencing sea water inundation either for a short time or for a long time. Sea water immersion will damage flexible pavement. Feng et al. in 2010 stated that salt has a significant effect on the asphalt binders performance on low temperature [10]. Asphalt concrete performance in sulfate solution is more severe than in water. The brucite fiber in the mixture has an excellent effect on enhancement, stability, and reinforcement [11].

The road pavement surface damage factor is one of the causes of traffic accidents [12]. It is necessary to seek efforts to repair road damage. High concentration of salt spray in the environment deteriorates asphalt mixtures durability [13]. Chen and $X U$ investigate the fibers in reinforcing effects and mechanisms for stabilizing and reinforcing asphalt binder. Fibers improve asphalt binder's resistance to rutting, flow, and dynamic shear modulus [14]. Tahmoorian and Samali using recycled construction aggregate in asphalt mixtures. Mixtures containing recycled construction aggregate have better workability, deformation resistance and compaction in comparison with basalt [15]. The previous study, Sugiyanto in 2017 identified the asphalt concrete characteristic produced from scrapped tire rubber. Scrapped tire rubber can improve resistance to permanent deformation due to ruts, provide better resistance in high temperatures [16], and resistance to water [17]. Liu et al. added the steel wool [18] and Do et al. using recycled waste lime in asphalt concrete mixture. Recycled waste lime improves stiffness, permanent deformation characteristics, and fatigue endurance of asphalt concrete [19]. Bowers et al. in 2014 investigated the reclaimed asphalt pavement blending efficiency through gel permeation chromatography. Blending occurs throughout all layers of the asphalt mixture [20]. As mentioned by Ge et al. in 2017 penetration and asphalts ductility decreased and softening point of asphalts increased after modified with Sasobit and Polyphosphoric acid [21]. The other study, addition of nanoclay and carbon microfiber improve mixture's moisture susceptibility performance [22]. Polyester fibers improve properties of asphalt mixture [23]. The pulling rate and asphalt film thickness have an equivalent relation. As mentioned by Huang et al. binder bond strength tests could be applied to reflect mixture resistance in modified asphalt mixtures [24].

One effort that can be tried to reduce the damage to flexible pavements due to sea water immersion is addition of buton asphalt into a modified mixture. The Buton Asphalt (as-buton) is natural rock asphalt in Lawele, South Buton Island, Southeast Sulawesi, Indonesia. As-buton consists of $20-35 \%$ high quality bitumen and $65-80 \%$ limestone filler. The total deposit is estimated at 650 million tones [25]. The advantages of As-buton are that it has higher adhesion and more resistance to temperature changes so that it is expected to increase stability to water. The aim of this research is to identify the effect of sea water immersion on asphalt concrete modification as-buton. Experimental investigation based on characteristics of Marshall conducted to determine the effect of sea water on the modification asphalt containing as-buton. The novelty of this research is that the composition of the modified as-buton mixture was produced and the effect of the as-buton mixture in sea water immersion was based on Marshall characteristic test results.

\subsection{METHODOLOGY}

\subsection{Asphalt Mixture and Gradation of Aggregate}

In this research, a layer of asphalt concrete type namely Asphalt Concrete-Wearing Course (AC-WC) with maximum aggregate size is $19 \mathrm{~mm}$. The aggregate gradations limit specification by the Ministry of Public Work Republic of Indonesia: Bina Marga 2010 (Revision 3) as stated in Table 1 [26].

\subsection{Material}

Materials in this research consists of coarse and fine aggregate, filler using stone ash, asphalt Buton, asphalt with the penetration grade 60-70 from PERTAMINA, Indonesia and sea water. Asphalt buton from deposits on Lawele, South Buton Island, Southeast Sulawesi. Sea water used in this research is taken from Teluk Penyu Beach, in Cilacap District, Central Java Province, Indonesia. The characteristics of the sea water from Teluk Penyu Beach, salinity value $25 \%$ and the Potential of Hydrogen $(\mathrm{pH})$ value 8.52. 
Table 1 Specification of aggregate gradation limits for ACWC Mixture [26]

\begin{tabular}{|c|c|c|c|}
\hline \multirow{2}{*}{$\begin{array}{c}\text { Size of } \\
\text { sieve }(\mathrm{mm})\end{array}$} & \multirow{2}{*}{$\begin{array}{c}\text { Sieve } \\
\text { number }\end{array}$} & \multicolumn{2}{|c|}{ Percentage passing of sieve (\%) } \\
\hline & & Lower limit & Upper limit \\
\hline 19.1 & $3 / 4$ inch & - & 100 \\
\hline 12.7 & $1 / 2$ inch & 90 & 100 \\
\hline 9.52 & $3 / 8$ inch & 77 & 90 \\
\hline 4.76 & No. 4 & 53 & 69 \\
\hline 2.38 & No. 8 & 33 & 53 \\
\hline 1,18 & No. 16 & 21 & 40 \\
\hline 0.59 & No. 30 & 14 & 30 \\
\hline 0.279 & No. 50 & 9 & 22 \\
\hline 0.149 & No. 100 & 6 & 15 \\
\hline 0.074 & No. 200 & 4 & 9 \\
\hline
\end{tabular}

\subsection{Methods}

The test methods and standards for coarse and fine aggregate and asphalt followed the Indonesian specification or Standard National of Indonesia (SNI). The conducted tests are water absorption, specific gravity, abrasion, adhesive of aggregate and asphalt. Standards used namely SNI 1969-2008 [27] for bulk specific gravity and water absorption test, SNI 2417-2008 [28] for abrasion test, SNI 06-2456-2011 [29] for penetration test of asphalt, SNI 2441-2011 [30] for specific gravity of asphalt test, SNI 2432-2011 [31] for ductility asphalt test, SNI 2433-2011 [32] for flash and fire point of asphalt test, SNI 2434-2011 [33] for softening point of bitumen test, and SNI 7729-2011 [34] for viscosity asphalt test. Asphalt content ranges from 4.5 to $6.5 \%$ based on the study by Sugiyanto et al. in 2015 [35]. To determine the optimum asphalt content, the AC-WC mixture was varied from 4.5 to $6.5 \%$ at $0.5 \%$ interval. The specimens were immersed in freshwater and sea water for up to 24 hours at a temperature of $30^{\circ} \mathrm{C}$.

Seven characteristics of Marshall Test namely void in mixture, void in mineral aggregate, voids filled with asphalt, flow, stability, Marshall quotient, and density. Total samples in this study are 39 units, 15 samples for Marshall Test characteristic to get the optimum asphalt content value from AC-WC mixture and 24 samples for fresh water and sea water immersion test. There are 9 samples of modification buton as-buton for fresh water immersion test, and 9 samples of asbuton mixture for sea water immersion test. The percentage by weight of as-buton used is $5 \%, 7.5 \%$, and $10 \%$. The number of samples of each asphalt content is 3 samples. Details of the mixture type and number of samples of AC-WC mixture for Marshall Test characteristic are shown in Table 2. Details of the number of samples of asphalt mixture and modification as-buton mixture (The percentage by weight of as-buton $5 \%, 7.5 \%$ and $10 \%$ ) for freshwater and sea water immersion test are shown in Table 3.
Table 2 Number of samples of AC-WC mixture for Marshall Test

\begin{tabular}{ccc}
\hline Mixture type & $\begin{array}{c}\text { Asphalt } \\
\text { content (\%) }\end{array}$ & $\begin{array}{c}\text { The number of } \\
\text { samples }\end{array}$ \\
\hline AC-WC & 4.5 & 3 \\
AC-WC & 5.0 & 3 \\
AC-WC & 5.5 & 3 \\
AC-WC & 6.0 & 3 \\
AC-WC & 6.5 & 3 \\
& Total & 15 \\
\hline
\end{tabular}

Table 3 Number of samples of asphalt mixture for freshwater and sea water immersion test

\begin{tabular}{ccc}
\hline $\begin{array}{c}\text { Asphalt Buton } \\
\text { content } \\
(\%)\end{array}$ & $\begin{array}{c}\text { The number of samples } \\
\text { Freshwater } \\
\text { immersion }\end{array}$ & $\begin{array}{c}\text { Sea water } \\
\text { immersion }\end{array}$ \\
\hline 0 & 3 & 3 \\
5 & 3 & 3 \\
7.5 & 3 & 3 \\
10 & 3 & 3 \\
Total & 12 & 12 \\
\hline
\end{tabular}

\subsection{RESULTS AND DISCUSSION}

\subsection{Aggregate Test Results}

The aggregate physical properties and characteristics of coarse aggregate, fine aggregate, and filler are determined based on the aggregate tests. The physical properties test results of coarse aggregate include specific gravity, water absorption, and abrasion test as shown in Table 4. The physical properties of fine aggregate and filler can be seen in Table 5.

Table 4 Physical properties of coarse aggregate

\begin{tabular}{|c|c|c|c|}
\hline Tests (unit) & Result & Specification & Standard \\
\hline $\begin{array}{l}\text { Bulk specific gravity } \\
\text { (gr/cc) }\end{array}$ & 2.57 & Min. 2.50 & SNI 1969-2008 \\
\hline $\begin{array}{l}\text { SSD specific gravity } \\
\text { (gr/cc) }\end{array}$ & 2.58 & Min. 2.50 & SNI 1969-2008 \\
\hline $\begin{array}{l}\text { Effective specific gravity } \\
\text { (gr/cc) }\end{array}$ & 2.58 & Min. 2.50 & SNI 1969-2008 \\
\hline Water absorption (\%) & 0.28 & Max. 3\% & SNI 1969-2008 \\
\hline $\begin{array}{l}\text { Abrasion test with Los } \\
\text { Angeles machine } 100 \\
\text { rotations (\%) }\end{array}$ & 4 & Max. $6 \%$ & SNI 2417-2008 \\
\hline $\begin{array}{l}\text { Abrasion test with Los } \\
\text { Angeles machine } 500 \\
\text { rotations (\%) }\end{array}$ & 11 & Max. $30 \%$ & SNI 2417-2008 \\
\hline
\end{tabular}

Based on Table 4, the physical properties test results of coarse aggregate include: bulk specific gravity is 2.57 (min. specification 2.50), water absorption $0.28 \%$ (max. specification 3\%), the abrasion with Los Angeles Machine 100 rotation for asphalt mixture 4\% (max. specification 6\%), and the 
abrasion with Los Angeles Machine 500 rotation for as-buton modification mixture $11 \%$ (max. specification $30 \%)$. It means that coarse aggregate: crushed stone is complying with required specification standards and can be used as a coarse aggregate in asphalt concrete mixture and as-buton modification mixture. Based on Table 5, the result of physical properties of fine aggregate are water absorption is $0.42 \%$ (max. specification $3 \%$ ), the bulk specific gravity is 2.56 (min. specification 2.50). The specific gravity of stone ash as filler in the asphalt mixture is 2.56 (min. specification 2.5). The results of aggregate gradation examination obtained the percentage of coarse aggregate, namely aggregate grains which have a larger grain size than sieve no. $4(4.76 \mathrm{~mm})$ of $39 \%$. Fine aggregate which has a finer grain size than sieve no. $4(4.76 \mathrm{~mm})$ of $54.5 \%$ and filler is $6.5 \%$.

Table 5 Physical properties of fine aggregate and filler

\begin{tabular}{lccc}
\hline \multicolumn{1}{c}{ Tests (unit) } & Result & Specification & Standard \\
\hline $\begin{array}{l}\text { Bulk specific gravity of } \\
\text { fine aggregate (gr/cc) }\end{array}$ & 2.56 & Min. 2.50 & SNI 1969-2008 \\
$\begin{array}{l}\text { SSD specific gravity of } \\
\text { fine aggregate (gr/cc) }\end{array}$ & 2.57 & Min. 2.50 & SNI 1969-2008 \\
$\begin{array}{l}\text { Effective specific gravity } \\
\text { of fine aggregate (gr/cc) }\end{array}$ & 2.57 & Min. 2.50 & SNI 1969-2008 \\
$\begin{array}{l}\text { Water absorption (\%) } \\
\text { Filler specific gravity (gr/cc) }\end{array}$ & 0.42 & Max. 3\% & SNI 1969-2008 \\
\hline
\end{tabular}

\subsection{Asphalt Test Results}

Asphalt with the penetration grade 60-70 from PERTAMINA, Indonesia was used in this research. Asphalt test includes penetration of asphalt, softening point, ductility, specific gravity, flash and fire point, and viscosity. The asphalt test results can be seen in Table 6. The asphalt buton modification test results with $5 \%, 7.5 \%$ and $10 \%$ as-buton can be seen in Table 7.

Table 6 Asphalt test results

\begin{tabular}{lccc}
\hline \multicolumn{1}{c}{ Tests (Unit) } & Result & Specification & Standard \\
\hline Penetration (dmm) & 63.6 & $60-70$ & SNI 06-2456- \\
& & & 2011 \\
Softening point $\left({ }^{\circ} \mathrm{C}\right)$ & 54 & $\geq 48$ & SNI 2434-2011 \\
Flash point $\left({ }^{\circ} \mathrm{C}\right)$ & 282 & Min. 200 & SNI 2433-2011 \\
Fire point $\left({ }^{\circ} \mathrm{C}\right)$ & 333 & - & SNI 2433-2011 \\
Ductility $(\mathrm{cm})$ & 124.5 & Min. 100 & SNI 2432-2011 \\
Specific gravity (gr/cc) & 1.046 & $\geq 1.00$ & SNI 2441-2011 \\
Viscosity $(\mathrm{CSt})$ & & - & SNI 7729-2011 \\
Mixing temp. $\left({ }^{\circ} \mathrm{C}\right)$ & 153 & & \\
Compaction temp. $\left({ }^{\circ} \mathrm{C}\right)$ & 143.5 & & \\
\hline
\end{tabular}

Based on Table 6 , the penetration test in temperature $25^{\circ} \mathrm{C}$ is $63.6 \mathrm{dmm}$ (specification 60-70 $\mathrm{dmm}$ ). The softening point of asphalt based on the ring and ball test method is $54^{\circ} \mathrm{C}$ (min. specification $48^{\circ} \mathrm{C}$ ). Based on the penetration value and softening point of asphalt can be analyzed the penetration index. Flash and fire points of asphalt using Cleveland open cup method [32]. The value of the flash point is $282^{\circ} \mathrm{C}$ (min. specification $200^{\circ} \mathrm{C}$ ) and the fire point of asphalt is $333^{\circ} \mathrm{C}$. The ductility of asphalt is $124.5 \mathrm{~cm}$ (specification $\geq 100 \mathrm{~cm}$ ). The specific gravity value of asphalt is 1.046 (min. specification 1.0). Asphalt with the penetration grade $60-70$ from PERTAMINA is compliant with the required specification Bina Marga 2010 (Rev. 3) and can be used as bitumen in AC-WC mixture.

Table 7 As-buton modification test results

\begin{tabular}{lcccc}
\hline \multicolumn{1}{c}{ Tests (unit) } & Asphalt buton content (\%) & $\begin{array}{c}\text { Speci- } \\
\text { fication }\end{array}$ \\
\hline Penetration (dmm) & $\mathbf{5}$ & $\mathbf{7 . 5}$ & $\mathbf{1 0}$ & Min. 50 \\
Softening point $\left({ }^{\circ} \mathrm{C}\right)$ & 54.4 & 52 & 51.5 & Mi.7 \\
Ductility (cm) & 104.5 & 102.5 & 100 & $\geq 53$ \\
Specific gravity (gr/cc) & 1.060 & 1.078 & 1.097 & $\geq 1.00$ \\
\hline
\end{tabular}

Based on Table 7, the penetration value for asbuton modification $5 \%$ is $53 \mathrm{dmm}$, as-buton modification $7.5 \%$ is $52 \mathrm{dmm}$, and $51.5 \mathrm{dmm}$ for asbuton modification 10\% (min. specification $50 \mathrm{dmm}$ ). The softening point of asphalt based on the ring and ball test method is $54.4^{\circ} \mathrm{C}$ for $5 \%$ as-buton, $54.7^{\circ} \mathrm{C}$ for $7.5 \%$ as-buton, and $55^{\circ} \mathrm{C}$ (min. specification $53^{\circ} \mathrm{C}$ ). The specific gravity of as-buton modification $5 \%$ is $1.060,7.5 \%$ is 1.078 , and 1.097 for as-buton $10 \%$ (min. specification 1.0). As-buton modification is complying with the required specification Ministry of Public Works Bina Marga 2010 (Rev. 3) [26].

\subsection{Marshall Test Result}

Marshall tests characteristic for the AC-WC or Asphalt Concrete-Wearing Course mixture with asphalt content range from 4.5 to $6.5 \%$. Seven characteristics of Marshall Test namely Void in Mixture (VIM in \% volume), Void in Mineral Aggregate (VMA in \% volume), Voids Filled with Asphalt (VFA in \% VMA), flow in $\mathrm{mm}$, stability in $\mathrm{kg}$. Marshall Quotient (MQ) in $\mathrm{kg} / \mathrm{mm}$ and density in $\mathrm{gr} / \mathrm{cc}$. Specification for Marshall Test based on specification Bina Marga 2010 (Rev. 3) [26]. Marshall Test results for AC-WC mixture for seven characteristics can be seen in Figure 1.

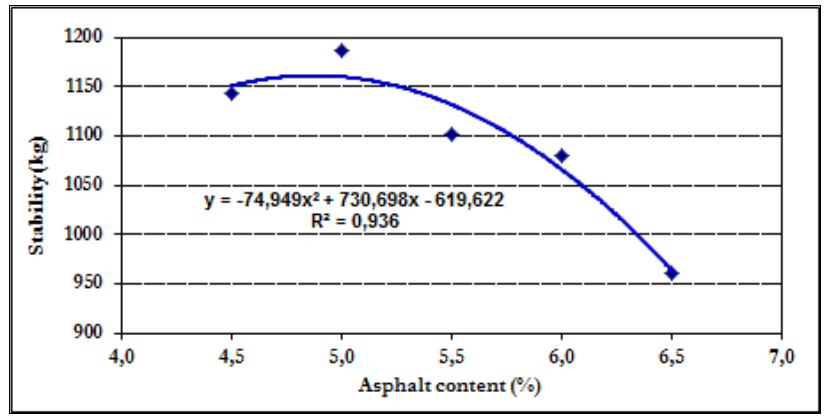

a. Relationship asphalt content and stability 


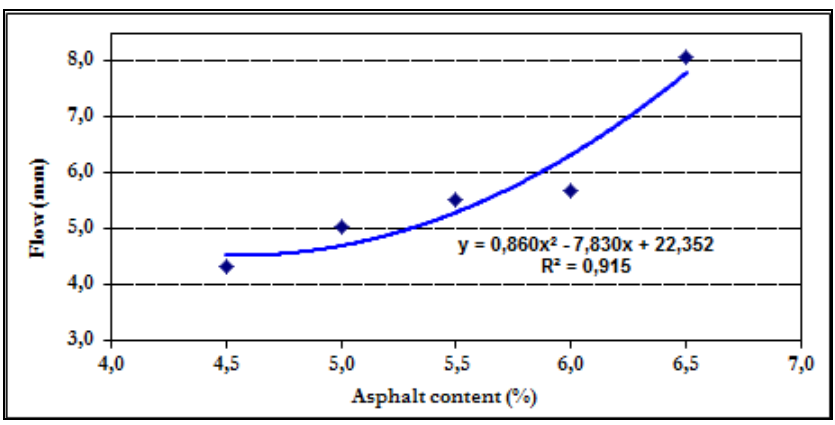

b. Relationship asphalt content and flow

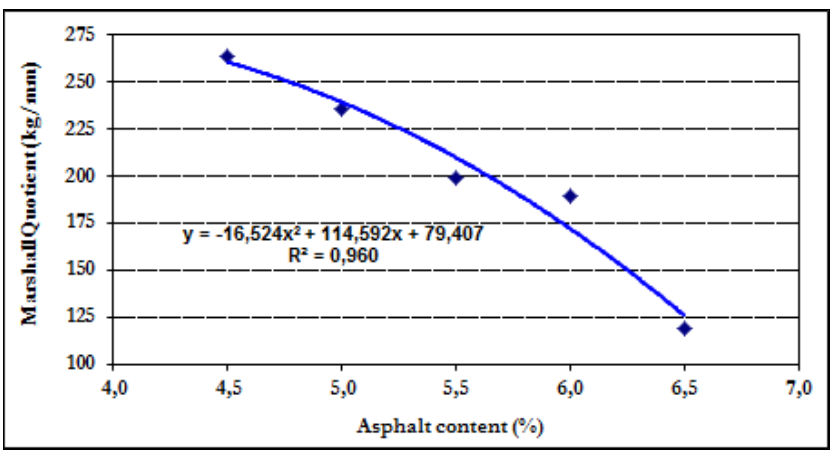

c. Relationship asphalt content and marshall quotient

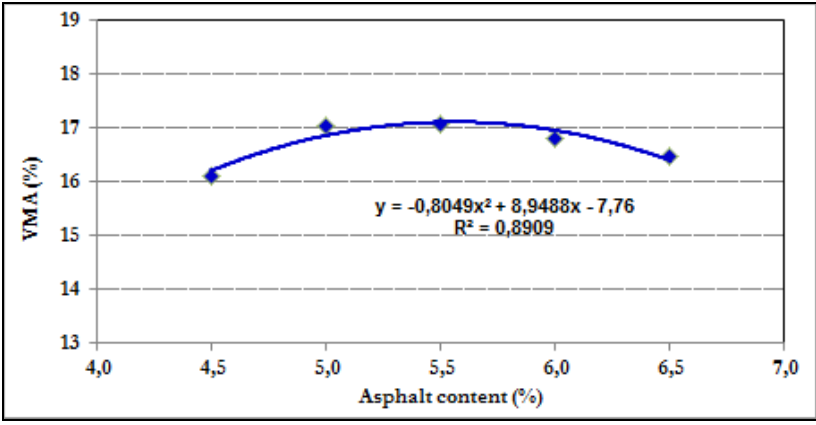

d. Relationship asphalt content and void in mineral aggregate

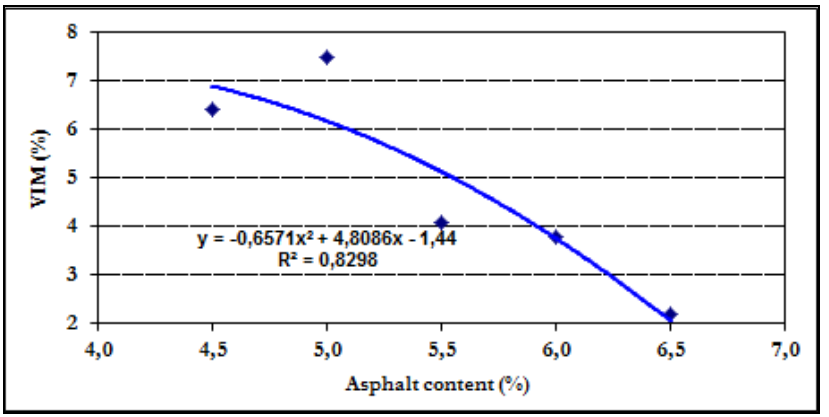

e. Relationship asphalt content and void in mixture

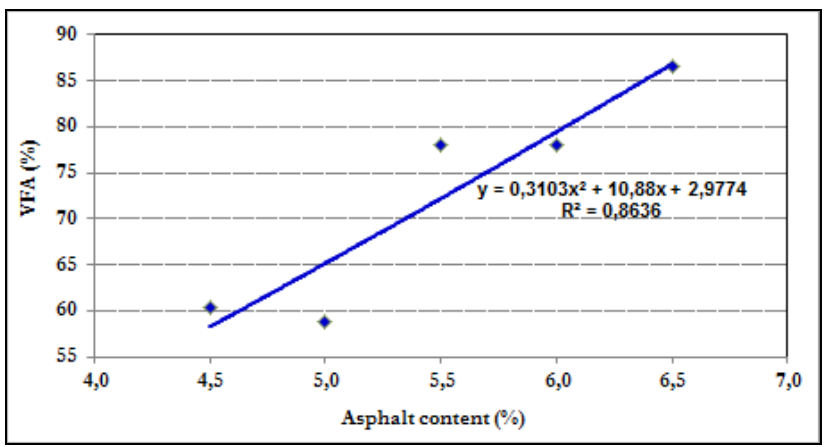

f. Relationship asphalt content and voids filled with asphalt

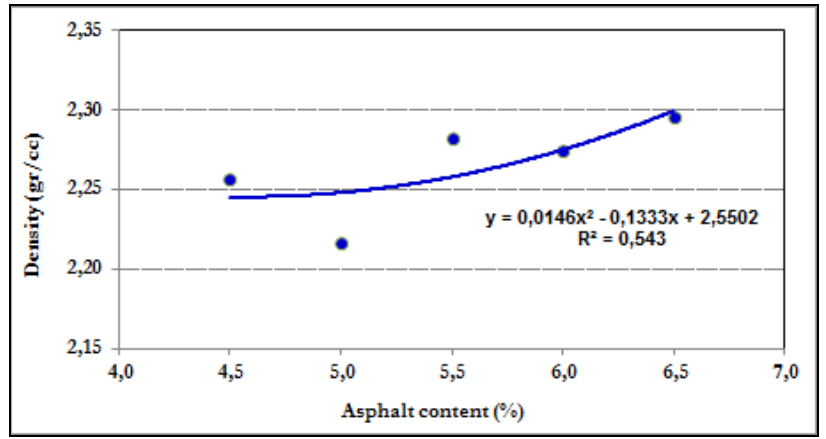

g. Relationship asphalt content and density

Figure 1 Marshall Test analysis results for AC-WC mixture

As depicted in Figure 1, the results of Marshall test characteristics show that the stability value of asphalt mixture will increase with the addition of mixed asphalt content and decrease if added asphalt content exceeds the optimum asphalt content value. Based on the specification from the Minister of Public Works: Bina Marga 2010 (Rev. 3), the minimum requirement value for stability of $A C-W C$ mixture is $800 \mathrm{~kg}$ [26], so that the AC mixture with asphalt content from 4.5 to $6.5 \%$ is complying with the specification standard. The second parameter flow value shows the amount of reduction in the mixture of test objects due to the load to the limit of collapse.

The flow result test of AC-WC mixture is increasing with the addition of asphalt content. For the asphalt content value from 4.5 to $6.5 \%$, the flow value of asphalt mixture is $4.33-8.07 \mathrm{~mm}$ ( $\geq 3 \mathrm{~mm}$ ), so that the asphalt mixture is complying with the required specification standard for the asphalt content from 4.5 to $6.5 \%$. The third parameter Marshall Quotient (MQ) values for AC-WC mixture is 119.14 to 263.92 $\mathrm{kg} / \mathrm{mm}$ (min. $250 \mathrm{~kg} / \mathrm{mm}$ ) [26]. The MQ values for ACWC mixture is complying with the required specification for asphalt content from 4.5 to $4.75 \%$. VMA shows the percentage of the number of air voids in the aggregate that can be filled with asphalt. The greater of the air voids between the aggregate grains, the greater the value of the air voids in the mixture. The VMA value for asphalt content of $4.5-6.5 \%$ obtained a value of 16.122 to $17.077 \%$, it has complied with the requirements of the Highways specification is $14 \%$. The VFA value shows the amount of cavity in the mixture filled with asphalt. 
The VFA value from test results obtained from 58.849 to $86.585 \%$. The minimum requirement for a VFA value is $63 \%$.

The determination of optimum asphalt content value for the AC-WC mixture based on Marshall Test characteristics is shown in Figure 2. In the AC-WC mixture, seven characteristics of Marshall Test include: stability, flow, VMA, and density value are appropriate for the asphalt content from 4.5 to $6.5 \%$. VIM value is appropriate for asphalt content from 5.34 to $6.235 \%$, VFA appropriate for asphalt content from 4.848 to $6.5 \%$ and $M Q$ for asphalt content 4.5 to $4.75 \%$. The asphalt content that can satisfy six specifications of Marshall Test characteristic is from 5.34 to $6.235 \%$. So the optimum asphalt content value of the AC-WC mixture is the median from 5.34 to $6.235 \%$ is $5.79 \%$ (indicated by the blue arrow in Figure 2).

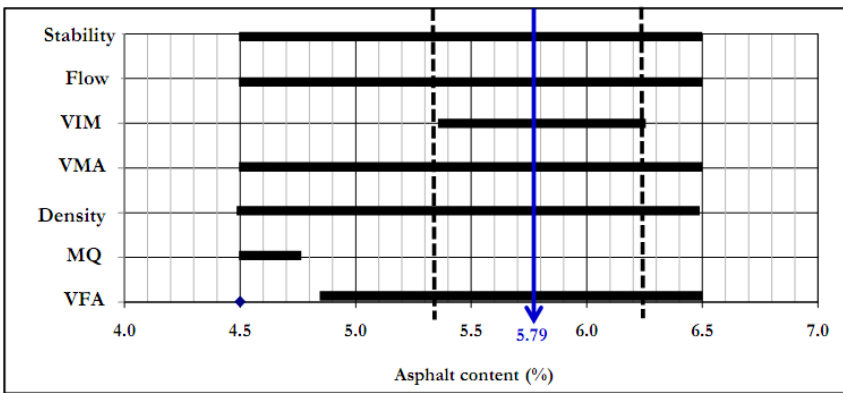

Figure 2 Optimum asphalt content determination for the ACWC mixture

The value of each Marshall Test analysis results for the AC-WC mixture with optimum asphalt content $5.79 \%$ is shown in Table 8 . The specification of each parameter based on the Minister of Public Works: Bina Marga 2010 (Rev. 3) [26].

Table 8 Marshall Test analysis results for AC-WC with optimum asphalt content $5.79 \%$

\begin{tabular}{ccc}
\hline Marshall Test & Result for $\mathbf{5 . 7 9 \%}$ & Specification \\
\hline Stability $(\mathrm{kg})$ & 1098.52 & Min. 800 \\
Flow $(\mathrm{mm})$ & 5.85 & Min. 3 \\
MQ $(\mathrm{kg} / \mathrm{mm})$ & 188.94 & Min. 250 \\
VMA (\%) & 17.1 & Min. 14 \\
VIM (\%) & 4.37 & $3-5.5$ \\
VFA (\%) & 76.36 & Min. 63 \\
Density (gr/cc) & 2.249 & - \\
\hline
\end{tabular}

Based on Table 8, with optimum asphalt content value for AC-WC mixture is $5.79 \%$, from seven characteristics Marshall tests only Marshall Quotient (MQ) that doesn't comply with the Bina Marga specification. The higher $M Q$ value, the higher stiffness of a mixture and more susceptible the mixture to cracking. A stability value of asphalt mixture that is too high will result in a pavement that is too stiff so that its durability is reduced. As for the other six parameters comply with the Bina Marga specifications. The void in mixture value of asphalt mixture must be maintained. Void in mixture value required for AC-WC mixture is between 3.5 to $5.5 \%$. The asphalt mixture with void in mixture or VIM value range between 3 to $5.5 \%$ is not susceptible to flowing, melting, and plastic deformation. A very high VFA value will cause bleeding. Based on the optimum asphalt content result, the next step is making the asphalt buton modification with the percentage by weight of as-buton used is $5 \%, 7.5 \%$, and $10 \%$.

\subsection{Marshall Immersion Test Result}

The results of Marshall immersion for AC-WC mixture (without as-buton (0\%) and asphalt buton modifications $5 \%$ (as-buton 5\%), as-buton $7.5 \%$, and as-buton $10 \%$ are shown in Table 9 that immersed in fresh water and Table 10 for sea water immersion up to 24 hours at temperature of $30^{\circ} \mathrm{C}$. Seven parameters of Marshall Test characteristics include stability, VIM or Void in Mixture, VMA or Void in Mineral Aggregate, VFA or Voids Filled with Asphalt, flow, Marshall Quotient (MQ), and density.

Table 9 Marshal test characteristics of modification asphalt buton mixture in fresh water immersion

\begin{tabular}{cccccc}
\hline $\begin{array}{c}\text { Marshal test } \\
\text { characteristics }\end{array}$ & $\mathbf{0}$ & $\mathbf{5}$ & $\mathbf{7 . 5}$ & $\mathbf{1 0}$ & $\begin{array}{c}\text { Speci- } \\
\text { fication }\end{array}$ \\
\hline Stability (kg) & 1159.01 & 1215.61 & 1250.12 & 1328.35 & Min.1000 \\
Flow (mm) & 7.5 & 7.4 & 6.0 & 5.6 & Min. 3 \\
MQ (kg/mm) & 154.535 & 164.271 & 208.354 & 237.206 & Min. 300 \\
VMA (\%) & 14.675 & 15.690 & 15.825 & 15.914 & Min. 15 \\
VIM (\%) & 1.50 & 2.90 & 3.20 & 3.60 & $3.5-5.5$ \\
VFA (\%) & 89.644 & 81.731 & 79.779 & 77.703 & Min. 65 \\
Density (gr/cc) & 2.330 & 2.303 & 2.299 & 2.297 & - \\
\hline
\end{tabular}

Table 10 Marshal test characteristics of modification asphalt buton mixture in sea water immersion

\begin{tabular}{|c|c|c|c|c|c|}
\hline \multirow{2}{*}{$\begin{array}{c}\text { Marshal test } \\
\text { characteristics }\end{array}$} & \multicolumn{4}{|c|}{ Asphalt buton content (\%) } & \multirow{2}{*}{$\begin{array}{c}\text { Speci- } \\
\text { fication }\end{array}$} \\
\hline & 0 & 5 & 7.5 & 10 & \\
\hline Stability (kg) & 2267.24 & 2738.19 & 3155.24 & 3528.94 & Min. 1000 \\
\hline Flov & 7.10 & & & 6.1 & \\
\hline$M Q(\mathrm{~kg} / \mathrm{mm})$ & 319.329 & 438.111 & 508.909 & 578.514 & Min. 300 \\
\hline VMA (\%) & 14.993 & 15.099 & 15.366 & 15.632 & Min. 15 \\
\hline VIM (\%) & 1.90 & 2.20 & 2.60 & 3.20 & $3.5-5.5$ \\
\hline VFA (\%) & 87.557 & 86.274 & 83.079 & 79.284 & Min. 65 \\
\hline Density (gr/cc) & 2.322 & 2.319 & 2.312 & 2.304 & . \\
\hline
\end{tabular}

\subsection{Before and After Immersion}

There are seven characteristics of Marshall Test of asphalt mixture in before and after immersion. Two conditions of immersions are in fresh water and sea water immersion. The comparison for seven characteristics of marshall test in before immersion and after immersion can be seen in Table 11. 
Table 11 Marshal test characteristics of asphalt mixture before and after immersion

\begin{tabular}{cccccc}
\hline $\begin{array}{c}\text { Marshal test } \\
\text { characteristics }\end{array}$ & Before immersion & \multicolumn{3}{c}{ After immersion } \\
Result & Spec. & $\begin{array}{c}\text { Fresh } \\
\text { water }\end{array}$ & $\begin{array}{c}\text { Sea } \\
\text { water }\end{array}$ & Spec. \\
\hline Stability (kg) & 1098.52 & Min. 800 & 1159.01 & 2267.24 & Min. 1000 \\
Flow (mm) & 5.85 & Min. 3 & 7.5 & 7.10 & Min. 3 \\
MQ (kg/mm) & 188.94 & Min. 250 & 154.535 & 319.329 & Min. 300 \\
VMA (\%) & 17.1 & Min. 14 & 14.675 & 14.993 & Min. 15 \\
VIM (\%) & 4.37 & $3-5.5$ & 1.50 & 1.90 & $3.5-5.5$ \\
VFA (\%) & 76.36 & Min. 63 & 89.644 & 87.557 & Min. 65 \\
Density (gr/cc) & 2.249 & - & 2.330 & 2.322 & - \\
\hline
\end{tabular}

\subsection{Discussion}

The comparison of Marshall test characteristics of asphalt mixture before and after immersion can be seen in Figure 3. The stability of the asphalt mixture before immersion was $1098.52 \mathrm{~kg}$ and increased $5.5 \%$ when soaked in fresh water and increased $106 \%$ when soaked in sea water. Stability value that is too high will cause the flexible pavement to become stiff so that its durability is reduced.

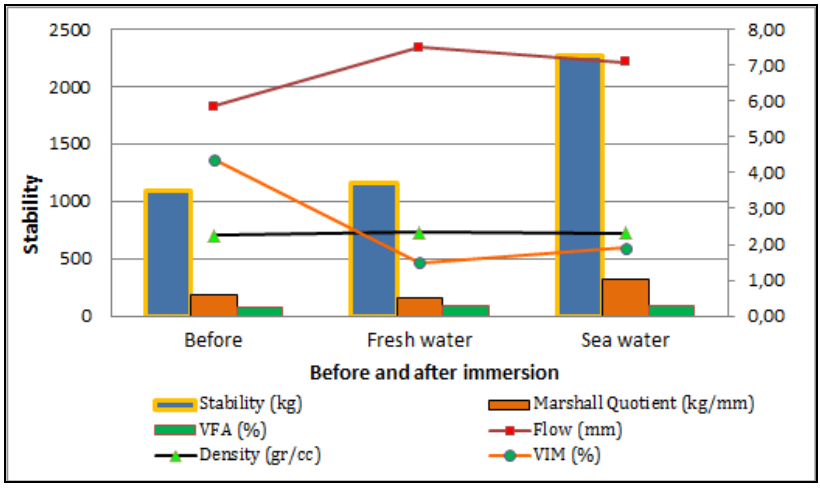

Figure 3 Comparison of Marshall test characteristics of asphalt mixture before and after immersion

The adding as-buton effect to the modified asphalt mixture and effect of soaking the mixture in sea water can be explained as follows: as depicted in Table 9 and Table 10, the results show that the asphalt mixture stability will increase with addition of as-buton content. This occurs because the bitumen contained in grain as-buton mixes with asphalt with the penetration grade $60 / 70$ in the asphalt mixture and causes the adhesion of the asphalt mixture to be better. The stability value of the modified asphalt buton mixture immersed in sea water is also greater than that immersed in fresh water. The increase in stability value due to the addition of as-buton as much as $10 \%$ in fresh water immersion reached $169.338 \mathrm{~kg}$ (increased by $14.61 \%$ ) while sea water immersion reached $1261.669 \mathrm{~kg}$ (increased by $55.65 \%)$.

Relationship between stability with as-buton content in fresh water and sea water immersion is shown in Figure 4. The addition of as-buton (as-buton) content in the asphalt mixture will result in a decrease in the flow value. The mobilization of bitumen from the as-buton grain causes the asphalt to become harder. The flow value of asphalt mixture immersed in fresh water decreased by $1.9 \mathrm{~mm}$ (decreased by 25.33\%), while those immersed in sea water decreased by $1 \mathrm{~mm}$ (decreased by $14.08 \%$ ). The higher the stability value, the more rigid the asphalt mixture, so that the level of durability decreases. Relationship between flow with as-buton content in fresh water and sea water immersion is shown in Figure 5.

The Marshall Quotient (MQ) value of the asphalt mixture increases with the addition of as-buton content. The $M Q$ value of the modified asphalt buton mixture immersed in sea water is greater than that immersed in fresh water. The increase in $M Q$ value due to the addition of $10 \%$ as-buton in freshwater immersion reached $82.67 \mathrm{~kg} / \mathrm{mm}$ (increased by $53.50 \%$ ) while in sea water immersion it reached $259.185 \mathrm{~kg} / \mathrm{mm}$ (increased by $81.17 \%$ ). The increase of $M Q$ value from modified asphalt buton immersed in sea water was greater than immersed in fresh water. Asphalt mixtures with as-buton grain substitution tend to be stiffer. Relationship between $M Q$ with as-buton content in fresh water and sea water immersion is shown in Figure 6.

The void in mineral aggregate (VMA) and void in mixture (VIM) values of asphalt mixture also increased with each addition of as-buton levels. The increase in VMA value in fresh water immersion reached $8.44 \%$ while in sea water immersion it increased by $4.26 \%$. The increase in the VIM value of the modified asbuton mixture immersed in fresh water reached $140 \%$ and in sea water it increased by $68.42 \%$. Meanwhile, the addition of as-buton content in the modified asbuton mixture tends to decrease the voids filled with asphalt (VFA) value. The VFA value in fresh water immersion decreased by $13.32 \%$ while that in sea water immersion decreased by $9.45 \%$. The effect of adding as-buton to the modified asphalt mixture on the density value is less significant. The difference in density values in the mixture without as-buton and asbuton substitution by $10 \%$ in freshwater immersion only decreased by $0.033(1.42 \%)$ and in sea water immersion decreased by $0.018 \quad(0.78 \%)$. The relationship between VMA with as-buton content in fresh water and sea water immersion is shown in Figure 7, relationship between VIM with as-buton content in fresh water and sea water immersion is shown in Figure 8, relationship between VFA with asbuton content in fresh water and sea water immersion is shown in Figure 9, and relationship between density with as-buton content in fresh water and sea water immersion is shown in Figure 10 respectively. 


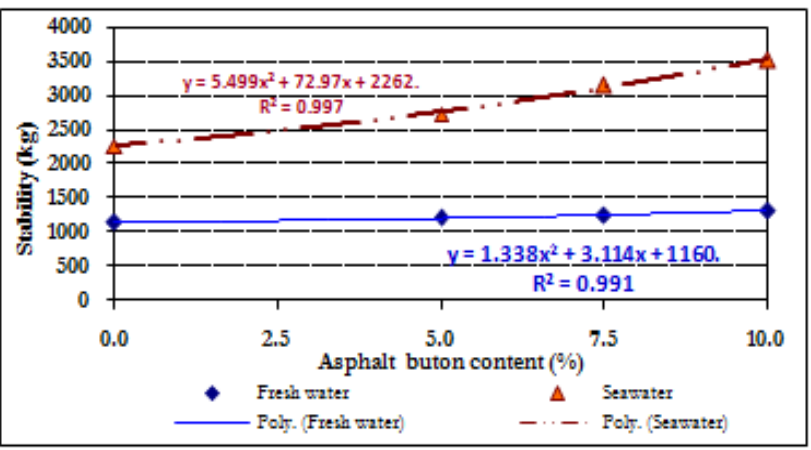

Figure 4 Relationship between stability with asphalt buton content in fresh water and sea water immersion

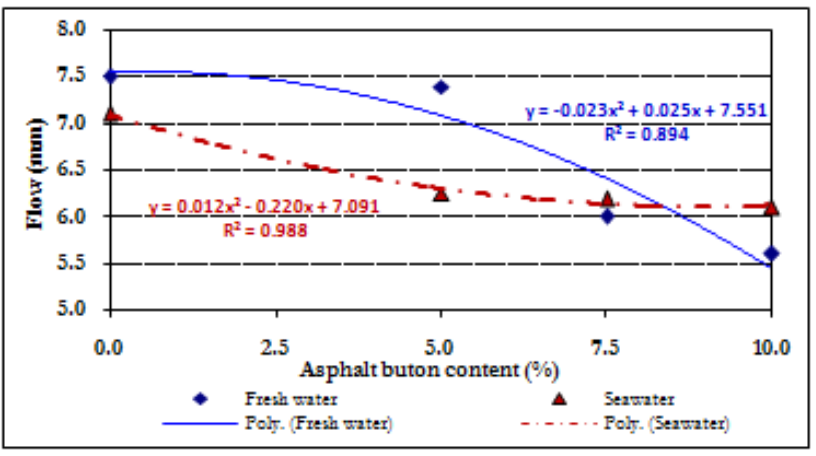

Figure 5 Relationship between flow with asphalt buton content in fresh water and sea water immersion

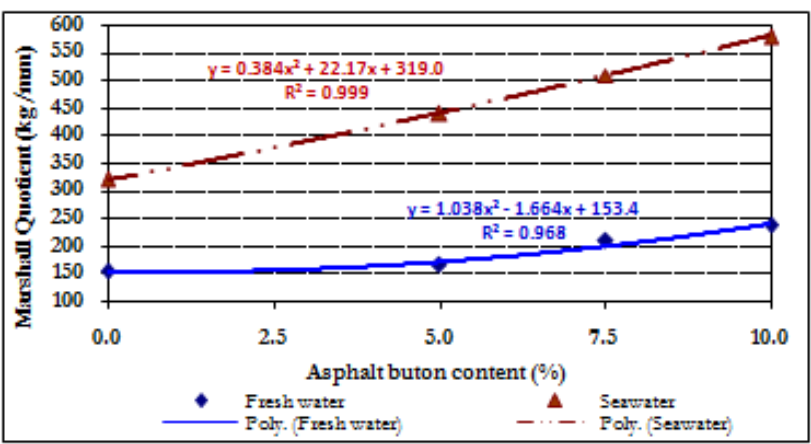

Figure 6 Relationship between Marshall Quotient with asphalt buton content in fresh water and sea water immersion

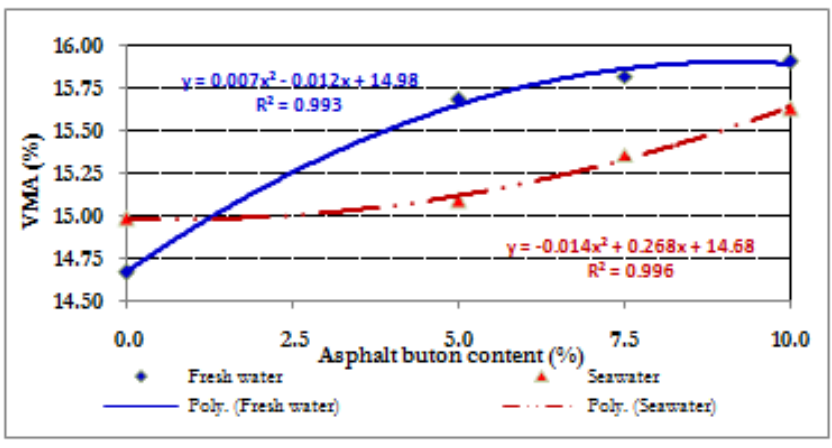

Figure 7 Relationship between VMA with asphalt buton content in fresh water and sea water immersion

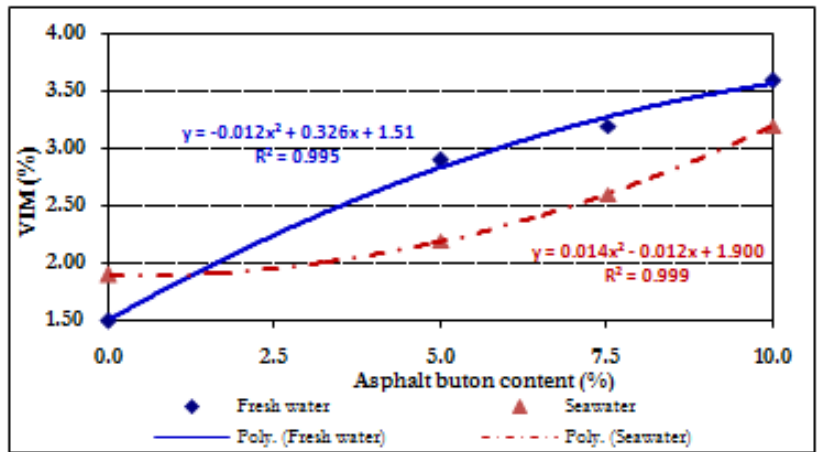

Figure 8 Relationship between VIM with asphalt buton content in fresh water and sea water immersion

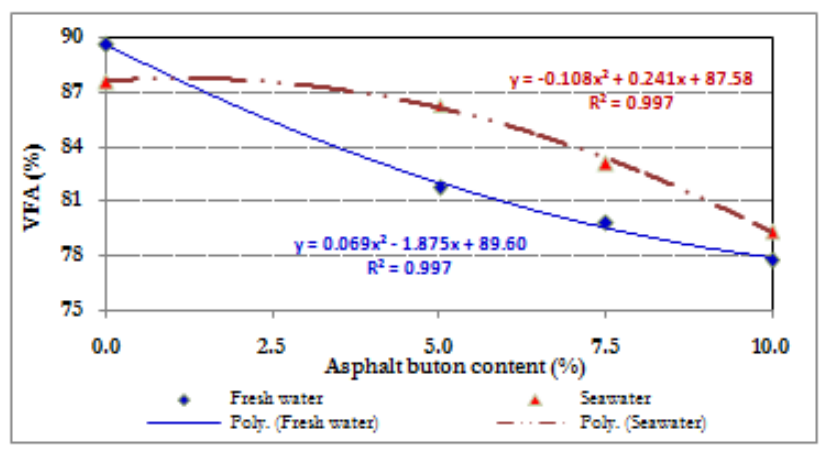

Figure 9 Relationship between VFA with asphalt buton content in fresh water and sea water immersion

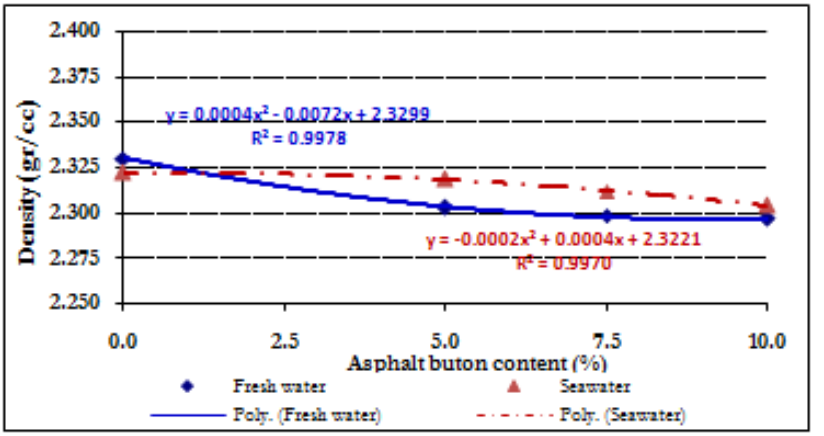

Figure 10 Relationship between density with asphalt buton content in fresh water and sea water immersion

One of the factors that influences moisture transport of asphalt mixtures is the void structures characterization [36]. The Improvement of the adhesive zone will result in porous asphalt concrete which will improved the durability, lifetime of mixture [37] [38], and reduce the tire-pavement noise [39] [40]. Because of some of these advantages, the porous asphalt pavement is more efficient than conventional pavements [41]. As mentioned by Ganesan et al. in 2013 the replacement of fine aggregate by shredded rubber as much as $15 \%$ and $20 \%$ improved the fatigue strength of self compacting rubberized concrete [42]. In the other study by Qin in 2015 which studied the strategy to mitigate the urban heat island effect using cool 
pavements development. The heat-harvesting pavements seem interesting to resolve the issue because they stay cool. The heat-harvesting pavements can also be used as a renewable energy source [43]. The interaction level between filler and bitumen is highly dependent on the polymer modification type [44]. Asphalt porous concrete mix had better aggregates interlocking, homogeneous void structure [45], improved adhesion properties, and higher number of asphalt fibrils with longer lengths relative to the neat asphalt [46].

Sea water immersion increases the stability of asphalt mixture, so that its durability is reduced. The result of this study is similar to the study by Millero [47] and Setiadji et al. [48]. Chloride in tidal water is the main contributor to damage on the asphalt pavement [48]. Effect of salt in performance of asphalt binders accelerates the failure when salt percentage is more than 3\% [49], increases the asphalt stiffening and decrease the adhesion [50], causes aggregate raveling in coastal areas [51], and water stability of mixture [52]. Sea water immersion has more influence on the value of stability, flow, and Marshall Quotient of asphalt mixture compared to fresh water immersion. The results of the comparison of sea water immersion in modified as-buton showed that addition of as-buton content increased stability and Marshall quotient value but decreased the flow value.

\subsection{CONCLUSION}

This research determines the effect of addition of asbuton to the modified asphalt mixture and the effect of sea water immersion on as-buton mixture based on the Marshall characteristic test. Through this study, the addition of as-buton makes the asphalt mixture more resistant to temperature changes and increases stability to water. The addition of as-buton increases the stability, void in mixture, Marshall quotient, and void in mineral aggregate, but reduces the value of flow, void filled with asphalt, and density. The stability and Marshall quotient value of the modified as-buton mixture immersed in sea water is greater than that in freshwater. The stability value with $10 \%$ modified as-buton mixture in freshwater immersion increased $14.61 \%$ and in sea water immersion increased $55.65 \%$. The flow value in freshwater immersion decreased $25.33 \%$ while in sea water immersion decreased $14.08 \%$. For further research, variations in the addition of as-buton will be carried out to obtain the optimum as-buton content which produces a modified asphalt mixture with the best performance.

\section{Acknowledgement}

"This research is supported by Jenderal Soedirman University". "The authors fully acknowledged the
Ministry of Research and Technology and Jenderal Soedirman University for the approved fund which makes this important research viable and effective".

\section{References}

[1] Chen, Z., Wu, S., Pang, L., and Xie, J. 2016. Function Investigation of Stone Mastic Asphalt (SMA) Mixture Partly Containing Basic Oxygen Furnace (BOF) Slag. Journal of Applied Biomaterials and Functional Materials. 14(1): 6872. DOI: https://doi.org/10.5301/jabfm.5000307.

[2] Sadeghnejad, M., Arabani, M., and Taghipoor, M. 2018. Predicting the Impact of Temperature and Stress on the Asphalt Mixtures' Rutting Behavior. International Journal of Pavement Research and Technology. 11: 300-310. DOI: https://doi.org/10.1016/j.ijprt.2017.10.006.

[3] Luo, D., Khater, A., Yue, Y., Abdelsalam, M., Zhang, Z., Li, Y., Li, J., Iseley, D. T. 2019. The Performance of Asphalt Mixtures Modified with Lignin fiber and Glass Fiber: A Review. Construction and Building Materials. 209: 377-387. DOI: https://doi.org/10.1016/j.conbuildmat.2019.03.126.

[4] Badan Pusat Statistik (BPS-Statistics Indonesia). 2020. Length of Roads by Surface Type Indonesia in 2018. https://www.bps.go.id/linkTableDinamis/view/id/820.

[5] Long, Y., Wu, S., Xiao, Y., Cui, P., and Zhou, H. 2018. VoCs Reduction and Inhibition Mechanisms of Using Active Carbon filler in Bituminous Materials. Journal of Cleaner Production. 181: 784-793. DOl: https://doi.org/10.1016/j.jclepro.2018.01.222.

[6] Mohod, M. V. and Kadam, K. 2016. A Comparative Study on Rigid and flexible Pavement: A Review. IOSR Journal of Mechanical and Civil Engineering. 13: 84-88. DOI: https://doi.org/10.9790/1684-1303078488.

[7] Liu, Z., Xing, M., Chen, S., He, R., and Cong, P. 2014. Influence of the Chloride-based Anti-freeze filler on the Properties of Asphalt Mixtures. Construction and Building Materials. 51: 133-140. DOl: https://doi.org/10.1016/j.conbuildmat.2013.09.057.

[8] Sugiyanto, G. and Malkhamah, S. 2018. Determining the Maximum Speed Limit in Urban Road to Increase Traffic Safety. Jurnal Teknologi (Sciences and Engineering). 80(5): 67-77. DOI: https://doi.org/10.11113/jt.v80.10489.

[9] Sugiyanto, G., Jajang, and Santi, M.Y. 2019. The Impact of Lowering Speed Limit on Mobility and the Environment. The $1^{\text {st }}$ International Conference on Material Science and Engineering for Sustainable Rural Development in AIP Conference Proceedings. 2094(1) 020019: 1-8. DOI: https://doi.org/10.1063/1.5097488.

[10] Feng, D., Yi, J., Wang, D. and Chen, L. 2010. Impact of Salt and Freeze-thaw Cycles on Performance of Asphalt Mixtures in Coastal Frozen Region of China. Cold Regions Science and Technology. 62(1): 34-41. DOI: https://doi.org/10.1016/j.coldregions.2010.02.002.

[11] Xiong, R., Chen, S. F., Guan, B. W., Cong, P. L. and Ma, L. L. 2011. Research on Performance of Asphalt Concrete Under the Action of Freeze-thaw and Corrosion. Journal Wuhan University of Technology. 33: 72-76. DOI: https://doi.org/10.3963/j.issn.1671-4431.2011.02.017.

[12] Sugiyanto, G., Fadli, A., and Santi, M. Y. 2017. Identification of Black Spot and Equivalent Accident Number using Upper Control Limit Method. ARPN Journal of Engineering and Applied Sciences. 12(2): 528-535. http://www.arpnjournals.org/jeas/research_papers/rp_201 7/jeas_0117_5650.pdf.

[13] Zhang, Q. and Huang, Z. 2019. Investigation of the Micro Characteristics of Asphalt Mastics under Dry-wet and Freeze-thaw Cycles in a Coastal Salt Environment. Materials. $\quad 12$ 2627-2646. https://doi.org/10.3390/mal2162627.

[14] Chen, H. and XU, Q. 2010. Experimental Study of fibers in Stabilizing and Reinforcing Asphalt Binder. Fuel. 89: 16161622. DOl: https://doi.org/10.1016/j.fuel.2009.08.020. 
[15] Tahmoorian, F. and Samali, B. 2018. Laboratory Investigations on the Utilization of RCA in Asphalt Mixtures. International Journal of Pavement Research and Technology. $\quad 11(6): \quad 627-638 . \quad$ DOl: https://doi.org/10.1016/j.jpprt.2018.05.002.

[16] Sugiyanto, G. 2017. Characterization of Asphalt Concrete Produced from Scrapped Tire Rubber. Engineering Journal. 21(4): 193-206. DOl: https://doi.org/10.4186/ej.2017.21.4.193.

[17] Sugiyanto, G. 2017. Marshall Test Characteristics of Asphalt Concrete Mixture with Scrapped Tire Rubber as a Fine Aggregate. Jurnal Teknologi (Sciences and Engineering). 79(2): 55-64. DOI: https://doi.org/10.11113/jt.v79.6965.

[18] Liu, Q., Yu, W., Schlangen, E., and van Bochove, G. 2014 Unravelling Porous Asphalt Concrete with Induction Heating. Construction and Building Materials. 71: 152-157. DOI: https://doi.org/10.1016/j.conbuildmat.2014.08.048.

[19] Do, H. S., Mun, P. H. and Keun, R. S. 2008. A Study on Engineering Characteristics of Asphalt Concrete using Filler with Recycled Waste Lime. Waste Management. 28(1): 191-199.

DOl: https://doi.org/10.1016/j.wasman.2006.11.011.

[20] Bowers, B. F., Huang, B. Shu, X., and Miller, B. C. 2014 Investigation of Reclaimed Asphalt Pavement Blending Efficiency Through GPC and FTIR. Construction and Building Materials. 50: 517-523.

DOI: https://doi.org/10.1016/j.conbuildmat.2013.10.003.

[21] Ge, D., Yan, K. You, L., and Wang, Z., 2017. Modification Mechanism of Asphalt Modified with Sasobit and Polyphosphoric Acid (PPA). Construction and Building Materials. 143: 419-428.

DOI: https://doi.org/10.1016/j.conbuildmat.2017.03.043.

[22] Goh, S.W, Akin, M., You, Z., and Shi, X. 2011. Effect of Deicing Solutions on the Tensile Strength of Micro-or NanoModified Asphalt Mixture. Construction and Building Materials. 5(1): 195-200. DOI: https://doi.org/10.1016/j.conbuildmat.2010.06.038.

[23] Ma, T., Geng, L., Ding, X., Zhang, D., and Huang, X. 2016. Experimental Study of Deicing Asphalt Mixture with AntiIcing Additives. Construction and Building Materials. 127: 653-662. https://doi.org/10.1016/j.conbuildmat.2016.10.018.

[24] Huang, W., Lv, Q., and Xiao, F. 2016. Investigation of using Binder Bond Strength Test to Evaluate Adhesion and SelfHealing Properties of Modified Asphalt Binders. Construction and Building Materials. 113: 49-56. DOI: https://doi.org/10.1016/j.conbuildmat.2016.03.047.

[25] Ministry of Public Works. 2006. Pedoman Konstruksi Bangunan No. 001-03/BM/2006. Pemanfaatan As-buton Buku 3 Campuran Beraspal Panas dengan As-buton Olahan. Jakarta: Ministry of Public Works Indonesia.

[26] Ministry of Public Works. 2014. Spesifikasi Umum Bina Marga Divisi 62010 (Revision 3). Jakarta: Directorate General of Highways, Ministry of Public Works Republic of Indonesia.

[27] Standar Nasional Indonesia (SNI) 1969:2008. 2008. Cara Uji Berat Jenis dan Penyerapan Air Agregat Kasar. Jakarta: Badan Standardisasi Nasional (BSN) Indonesia.

[28] Standar Nasional Indonesia (SNI) 2417:2008. 2008. Cara Uji Keausan Agregat dengan Mesin Abrasi Los Angeles. Jakarta: Badan Standardisasi Nasional (BSN) Indonesia.

[29] Standar Nasional Indonesia (SNI) 06-2456-2011. 2011. Cara Uji Penetrasi Aspal. Jakarta: Badan Standardisasi Nasional (BSN) Indonesia.

[30] Standar Nasional Indonesia (SNI) 2441-2011. 2011. Cara Uji Berat Jenis Aspal Keras. Jakarta: Badan Standardisasi Nasional (BSN) Indonesia. http://sni.litbang.pu.go.id/ index.php?r=/sni/new/sni/detail/id/237.

[31] Standar Nasional Indonesia (SNI) 2432-2011. 2011. Cara Uji Daktilitas Aspal. Jakarta: Badan Standardisasi Nasional (BSN) Indonesia. http://sni.litbang.pu.go.id/index. php?r=/sni/ new/sni/detail/id/232.

[32] Standar Nasional Indonesia (SNI) 2433-2011. 2011. Cara Uji Titik Nyala dan Titik Bakar Aspal dengan Alat Cleveland
Open Cup. Jakarta: Badan Standardisasi Nasional (BSN) Indonesia. http://sni.litbang.pu.go.id/index.php?r=/sni/ new/ sni/detail/id/233.

[33] Standar Nasional Indonesia (SNI) 2434-2011. 201 1. Cara Uji Titik Lembek Aspal dengan Alat Cincin Bola (Ring and Ball). Jakarta: Badan Standardisasi Nasional (BSN) Indonesia.

[34] Standar Nasional Indonesia (SNI) 7729-2011. 2011. Cara Uji Viskositas Aspal pada Temperatur Tinggi dengan Alat Saybolt Furol (Standard Test Method for Saybolt Furol Viscosity of Bituminous Materials at High Temperature). Jakarta: Badan Standardisasi Nasional (BSN) Indonesia.

[35] Sugiyanto, G., Hermawan, A. and Mulyono, B. 2015. The Characteristics of Asphalt Concrete-Binder Course (ACBC) Mixture with Bottom Ash as an Aggregate Substitute. Civil Engineering Dimension. 17(1): 29-37.

DOI: http://doi.org/10.9744

[36] Caro, S., Masad, E., Bhasin, A., and Little, D.N. 2008. Moisture Susceptibility of Asphalt Mixtures, Part 1: Mechanisms. International Journal of Pavement Engineering. 9(2): 81-98. DOl: https://doi.org/10.1080/10298430701792128.

[37] Mo, L. T., Huurman, M., Wu, S. P., and Molenaar, A. A. 2009. Ravelling Investigation of Porous Asphalt Concrete Based on Fatigue Characteristics of Bitumen-Stone Adhesion and Mortar. Materials \& Design. 30(1): 170-179. DOI: https://doi.org/10.1016/j.matdes.2008.04.031.

[38] Mo, L. T., Huurman, M., Wu, S. P., and Molenaar, A. A. 2011. Bitumen-stone Adhesive Zone Damage Model for the Meso-mechanical Mixture Design of Raveling Resistant Porous Asphalt Concrete. International Journal of Fatigue. 33(11): 1490-1503.

DOI: https://doi.org/10.1016/j.ijfatigue.2011.06.003.

[39] Chen, D., Ling, C., Wang, T., Su, Q., and Ye, A. 2018. Prediction of Tire Pavement Noise of Porous Asphalt Mixture based on Mixture Surface Texture Level and Distributions. Construction and Building Materials. 173: 801810.

DOI: https://doi.org/10.1016/j.conbuildmat.2018.04.062.

[40] Chu, L. J. and Fwa, T. F. 2019. A Functional Approach for Determining Skid Resistance Threshold State of Porous Pavement. International Journal of Pavement Engineering. 20(4): 481-489.

DOl: https://doi.org/10.1080/10298436.2017.1309195.

[41] Ahmad, K. A., Abdullah, M. E., Abdul Hassan, N., Daura, H. A., and Ambak, K. 2017. A Review of using Porous Asphalt Pavement as an Alternative to Conventional Pavement in Storm Water Treatment. World Journal of Engineering. 14(5): 355-362. DOI: https://doi.org/10.1 108/WJE-09-20160071.

[42] Ganesan, N., Raj, J. B., and Shashikala, A. P. 2013. Flexural Fatigue Behavior of Self-compacting Rubberized Concrete. Construction and Building Materials. 44: 7-14. DOI: https://doi.org/10.1016/j.conbuildmat.2013.02.077.

[43] Qin, Y. 2015. A Review on the Development of Cool Pavements to Mitigate Urban Heat Island Effect. Renewable and Sustainable Energy Reviews. 52: 445-459. DOI: https://doi.org/10.1016/j.rser.2015.07.177.

[44] Cardone, F., Frigio, F., Ferrotti, G., and Canestrari, F. 2015. Influence of Mineral fillers on the Rheological Response of Polymer-modified Bitumen and Mastics. Journal of Traffic and Transportation Engineering (English Edition). 2(6): 373381. DOI: https://doi.org/10.1016/j.jtte.2015.06.003.

[45] Poulikakos, L. D. and Partl, M. N. 2010. Investigation of Porous Asphalt Microstructure using Optical and Electron Microscopy. Journal of Microscopy. 240(2): 145-154. DOI: https://doi.org/10.1111/j.1365-2818.2010.03388.x.

[46] Khattak, M. J., Baladi, G. Y., and Drzal, L. T. 2007. Low Temperature Binder-aggregate Adhesion and Mechanistic Characteristics of Polymer Modified Asphalt Mixtures. Journal of Materials in Civil Engineering. 19(5): 411-422. DOI: https://ascelibrary.org/doi/abs/10.1061/ (ASCE)0899-1561 (2007) 19:5(411). 
[47] Millero, F. J. 2013. Physico-chemical controls on sea water. In Treatise on Geochemistry. Second Edition. Elsevier Inc. Ocean Sciences. 8: 1-18.

DOl: https://doi.org/10.1016/B978-0-08-095975-7.00601-X

[48] Setiadji, B.H., Utomo, S., and Nahyo. 2017. Effect of Chemical Compounds in Tidal Water on Asphalt Pavement Mixture. International Journal of Pavement Research and Technology. 10(2): 122-130.

DOI: https://doi.org/10.1016/j.jpprt.2016.11.002.

[49] Feng, D., Yi, J., Wang, D., and Chen, L. 2010. Impact Of Salt and Freeze-thaw Cycles on Performance of Asphalt Mixtures In Coastal Frozen Region of China. Cold Regions Science and Technology. 62(1): 34-41

DOI: https://doi.org/10.1016/j.coldregions.2010.02.002.
[50] Yang, H., Pang, L., Zou, Y., Liu, Q., and Xie, J. 2020. The Effect of Water Solution Erosion on Rheological, Cohesion and Adhesion Properties of Asphalt. Construction and Building Materials. 246: DOI: https://doi.org/10.1016/j.conbuildmat.2020.118465.

[51] Zhou, Z., Li, H., Liu, X., and He, W. 2020. Investigation of Sea Salt Erosion Effect on the Asphalt-aggregate Interfacial System. International Journal of Pavement Research and Technology. 13: 145-153.

DOI: https://doi.org/10.1007/s42947-019-0095-2.

[52] Zhong, K., Sun, M., and Chang, R. 2018. Performance Evaluation of High-elastic/Salt-Storage Asphalt Mixture Modified with Mafilon and Rubber Particles. Construction and Building Materials. 193: 153-161. DOI: https://doi.org/10.1016/j.conbuildmat.2018.10.185. 